\title{
MUSTAFA KEMAL PAŞA'NIN ERZURUM GÜNLERI (3 TEMMUZ 1919-29 AĞUSTOS 1919)
}

\author{
MUSTAFA KEMAL PASHA'S ERZURUM DAYS \\ (3 JULY 1919-29 AUGUST 1919)
}

\author{
МУСТАФА КЕМАЛЬ ПАША В ЭРЗРУМЕ \\ (03 ИЮЛЬ 1919 - 29 АВГУСТ 1919)
}

Dr. Mustafa ÖZYÜREK*

\section{ÖZ}

Erzurum şehri, Türk Tarihi açısından daima önemli bir yer olmuş, ancak en hareketli günlerini Milli Mücadele'nin teşkilatlanması aşamasında yaşamıştır. Çünkü Mondros Mütarekesi'nden sonra Türk vatanının çeşitli bahanelerle işgallere maruz kaldığı sırada ulusal birliğin ilk aşaması burada gerçekleşmiş, Türk'ün haklı feryadı bütün dünyaya buradan yükselmiştir. Erzurum'un bu kutlu yoldaki en eşsiz rolü de kuşkusuz, Türk'ün varlığına son vermek isteyen dâhili ve harici düşmanlara karşı mücadele bayrağını açan Mustafa Kemal Paşa'ya hayatının en zor günlerinde kucak açması olmuştur. Ev sahipliği yaptığı Erzurum Kongresi'nin toplanarak haksız işgallere dur demesi; manda ve himayeyi kesinlikle reddedip tam bağımsızlığı ülkü edinmesi, bu mücadelenin en büyük aşamasını teşkil etmiştir. Bu nedenle M. Kemal Paşa'nın Erzurum'da kaldığı yaklaşık iki aylık sürede gerçekleştirdiği faaliyetler, aziz vatanın işgallerden kurtarılması yolunda hayati derecede rol oynamıştır.

Anahtar Kelimeler: Erzurum, Mustafa Kemal Paşa, Milli Mücadele, Bağımsızlık

\section{ABSTRACT}

The city of Erzurum has always been a significant place in Turkish history, yet it has experienced the most stirred days during the National Struggle. It is because after the Armistice of Mondros, when the homeland of Turkish people was exposed to occupation for various reasons, the first stage of national unity was realized here and the rightful cry of Turks rose from here to all over the world. The unique role of Erzurum in that blessed path has been undoubtedly to embrace Mustafa Kemal Pasha in difficult days of his life, unfurling the battle flag against the internal and external enemies who wanted to put an end the presence of the Turks. Erzurum Congress, hosted in Erzurum, constituted the major stage of this struggle by stopping the unjustified occupations, rejecting absolutely mandate and commitment, and adopting full independence as an ideal. For this reason, activities conducted by $\mathrm{M}$. Kemal Pasha in Erzurum for two months played a vital role in rescuing precious homeland from the occupation.

Key Words: Erzurum, Mustafa Kemal Paşa, National Struggle, Independence

\section{АННОТАЦИЯ}

Город Эрзрум всегда занимал значительное место в истории Турции. Однако, самые будные времена своей истории город прожил во время национально - освободительной борьбы. Так как, после Мудросского пермирия, на окупированной по разным причинам турецкой земле, центром национального эдинства стал Эрзурум. Прававой зов турецкого народа по всему миру, начал распространятся с этого места. Эрзрум, несомненно занимает уникальную роль в этой благословленной борьбе. Город, в эти тяжёлые дни принял Мустафу Камаль Пашу, возведевшего пламя против внутренных и внешних врагов турецкой нации. В Эрзуруме состоялся конгресс, где было принято решение об остановлении несправедливог вторжения окупантов, отказе мандата, покровительства и о начале борьбы за полную независимость. В связи с этим, приезд М. Кемаль Паши в Эрзрум, побывание в теченни двух месяцев и его деятельность является действием жизненного значения в деле освобождения святой родины.

\footnotetext{
${ }^{*}$ Dr., Iğdır Üniversitesi Fen-Edebiyat Fakültesi Tarih Bölümü, Öğretim Elemanı. Mozyurek25mail.com
} 
Ключевые слова: Эрзурум, Мустафа Кемаль Паша, национально-освободительная война, независимость

\section{GİRIŞ̧}

Coğrafi özellikleri bakımından kartal yuvasına benzetilen Erzurum şehri; Aras, Çoruh ile Fırat nehirlerinin doğduğu ve Anadolu'ya hâkim bir merkezdir. Bu nedenle birçok medeniyete ev sahipliği yapan şehrin bilinen halkları arasında Urartular, Hititler, Ermeniler, Medler, Persler, Partlar, Romalılar, Sasaniler, Bizanslılar, Moğollar ve Türkler zikredilebilir. Erzurum'un önemi, bulunduğu jeopolitik konumundan kaynaklanmaktadır. Bundan dolayı tarih boyunca önemli bir yerleşim yeri olmuş ve bağlı olduğu siyasi teşekküllerin hayatında tarihi rol oynamıştır. (Konukçu: 4) Özellikle Rusya'nın, sıcak denizlere inmek gibi tarihi emelini gerçekleştirebilmek için öncelikle Kafkas'ları aşabilmesi gerekmekte olup, bunun yolu da Erzurum'un alınmasından geçmekteydi. 1928-1829 Osmanlı-Rus savaşları sonrası Rus ordusuyla birlikte Anadolu'ya gelen Aleksandr Sergeyeviç Puşkin "Erzurum Yolculuğu" adlı eserinde Erzurum'dan “Asya Anadolusunun Baş şehri” olarak bahsetmektedir.

Osmanlı Devleti'nin sonlarına doğru Rus işgaline uğrayan şehir, Brest-Litowsk Antlaşması'ndan sonra I. Kafkas Kolordusu tarafından kurtarılmışsa da 30 Ekim 1918 tarihli Mondros Mütarekesi'nin imzalanmasıyla bir kez daha Ermeni işgali ihtimaline maruz kalmıştı. Çünkü mütarekenin 24. maddesinde "Vilâyât-1 Sitte" olarak geçen doğu vilayetleri, mütarekenin İngilizce metninde "The Six Armenian Vilayets" olarak zikrolunmuştu. Bu da Doğu Anadolu'nun İtilaf Devletleri tarafından Ermenileştirileceği anlamına gelmekteydi. Bu ihtimal karşısında tepkisiz kalmayan aydınlar tarafindan önce İstanbul'da Vilâyat-i Şarkiyye-i Müdafaa-i Hukuk-1 Milliye Cemiyeti kurulmuş, ardından Erzurum'da cemiyetin bir şubesi açılarak bölgede milli mücadele başlatılmıştır. (Konukçu: 124) M. Kemal Paşa'nın Anadolu’ya geçmesinin ardından gerçekleştirdiği faaliyetler kapsamında Erzurum'a gelmesi ve Milli Mücadele'de Erzurum'un başlangıç noktası olarak seçilmesinin ne kadar doğru bir tespit olduğunu ortaya koymuştur. I. Dünya Savaşı öncesi 80.000 olan şehir nüfusunun büyük kısmı göç etmiş, on binlercesi salgın hastalıklar nedeniyle hayatını kaybetmiş ve on bin kadarı da Ermeniler tarafindan katledilmişti. Ancak şehrin Rus işgalinden kurtuluşundan sonra geri dönen göçmenler baba ocaklarına sahip çıkmaya başlamışlardı. Bunun en büyük sebebi ise bölgenin İtilaf Devletleri tarafından Ermenistan yapılacağına ilişkin kulaktan kulağa yayılan söylentilerdi. Bu nedenle büyük bir infial içerisinde bulunan halk tarafindan milli direniş birlikleri kurulmak suretiyle mücadele teşkilatlandırılmaktaydı. (Canım, 2010: 24-25)

İtilaf Devletleri mütarekenin imzalanmasından sonra, asayişsizlik alametleri ve Türklerin gayrimüslimlere karşı zulmü gibi asılsız gerekçeler ileri sürerek istedikleri yerleri işgal etmekteydiler. Karadeniz Bölgesi'nde de benzer hadiseler zuhur edince yaşananların giderilmesini Osmanlı Devleti'nden istemişlerdi. Bunun üzerine İstanbul hükümeti ve padişah, M. Kemal Paşa'yı ordu müfettişi olarak Samsun'a göndermişlerdi. O'ndan beklenen vazife ise durumu yerinde görerek gerekli tedbirleri alması idi. Bu tedbirler; bölgede asayişin sağlanması, dağınık halde bulunan silah ile mühimmatın toplatılması ve çeşitli yerlerde kurulan bazı şûraların lağvedilmesi idi. Ancak M. Kemal Paşa, firsattan istifade ederek, geniş yetkilerle Anadolu'ya gidebilmek için bu imkânı değerlendirmiştir. Aslında niyeti, başlamış olan milli mücadeleyi bir mihrak etrafında organize ederek Türk milletinin var olma mücadelesini açmaktı. (BTTG, 1968: 5) Böylece 15 Mayıs 1919'da İstanbul'dan ayrılan M. Kemal Paşa, beraberindeki heyetle birlikte 19 Mayıs 1919'da Samsun'a varmıştır. (Gürer, 1006: 234235; Gökbilgin, 1959: 83-87; Yalçın\&Koca, 2012)

M. Kemal Paşa Samsun'da bir süre kalarak ilk incelemelerini yaptıktan sonra 24 Mayıs 1919'da karargâhını Havza'ya taşımış ve 26 Mayıs 1919'da kendisini ziyarete gelen Havza eşrafina: "Hiçbir zaman ümitsiz olmayacağız, çalışacă̆ız, memleketi kurtaracă̆ız", diyerek her şeye rağmen ümitli olunması gerektiğini ifade etmiştir. Bir süre sonra ise güvenlik gerekçesiyle 13 Haziran'da Amasya'ya gitmiştir. Rauf Bey ile Ali Fuat Paşa da 19 Haziran'da Amasya'ya gelmiş ve daha sonra bunlara Refet Bey de kendilerine katılmıştı. İki üç gün süren müzakereler sonucunda fikirler daha da netleşmiş ve memleketi kurtarmak amacıyla ilk tarihi kararlar alınmıştı. M. Kemal Paşa İstanbul'da milli davayı sevk ve idare eden bazı kişilere gönderdiği özel mektuplarda, İstanbul'un artık Anadolu'ya ve milli hislere hâkim değil, tâbi olmak mecburiyetinde bulunduğunu söyledikten sonra, tarihte "Amasya Tamimi" olarak bilinen maddeler kararlaştırılmıştı. 21-22 Haziran tarihli bu genelgede; vatanın bütünlüğü ve milletin istiklâlinin tehlikede olduğu, İstanbul hükümetinin görevini yerine getiremediği, milletin bağımsızlığını yine milletin azim ve kararının kurtaracağı, her türlü baskı ve kontrolden uzak milli bir 
heyetin varlığının zaruri olduğu, Anadolu'nun en güvenli yeri olan Sivas'ta milli bir kongrenin toplanması gerektiği ve tüm bu meseleler bir sır olarak saklanmak suretiyle doğu illeri adına 10 Temmuz'da Erzurum' da bir kongrenin toplanacağı ifade edilmişti. (Gökbilgin, 1959: 150-158) Amasya Genelgesi ile İstanbul Hükümeti'ne karşı Anadolu'da milli bir hükümetin temelleri atılmak istenmiştir. (Bayar, 1997: 113)

\section{A. Mondros Mütarekesi Sonrası Erzurum}

I. Dünya Savaşı'nı sona erdiren Mondros Mütarekenamesi'nin 24. maddesinde "Vilâyât-1 Sitte" olarak geçen Erzurum, Bitlis, Sivas, Elazı̆̆ , Van ve Diyarbakır'dan mütarekenin İngilizce metninde "Armenia" olarak bahsedilmekte idi. Yine bu madde ile adı geçen vilayetlerin tamamının veya bir kısmının işgal hakkının da İtilaf Devletleri'nin muhafazasında olduğu kabul edilmekteydi. Bölgedeki aydın ve milletvekillerinin bir kısmı, bu hükmün meydana getireceği korkunç felaketleri önceden görerek, 2 Aralık 1919'da İstanbul'da "Vilâyât-1 Şarkiyye Müdafaa-i Hukuk-1 Milliye Cemiyeti"ni kurmuşlardı. (Kırzıoğlu, 1993: s. 4) Cemiyetin amacı, Doğu Anadolu topraklarının Ermenilere verilmesi ihtimaline karşı çıkarak bu toprakların Türk yurdu olduğunu siyasi ve ilmi açıdan ispat etmek, gerektiğinde bu gaye uğruna silahlı mücadeleye girişerek bölgedeki Türk halkının siyasi, dini ve milli haklarını korumaktı. (Çil, 2015: 3)

Erzurum çoğunluğunu İttihat ve Terakkicilerin oluşturduğu Teşkilât-1 Mahsusa'nın en önemli merkezlerinden biri olup, I. Dünya Savaşı yıllarında burada kurulan bir müfreze halen faal durumda idi. Ayrıca mütarekeden sonra Erzurum'daki bazı İttihatçıların girişimleri sonucu kurulan İstihlas-1 Vatan Cemiyeti üyeleri Süleyman Necati (Güneri) Bey'in sorumluluğu altında "Albayrak" gazetesi yeniden çıkarılarak milliyetçi fikirler işlenmeye başlanmıştı. (Konukçu, 1999: 7; Kılınçkaya\&Yavuz, 2003: 418419) Serhat şehri olan Erzurum'un Ermenilere verilmesine engel olmak ve milli direnişte bulunmak amacıyla cemiyetin Erzurum'da bir şubesini açmak için vilayete başvuru yapılmıştı. Başvurunun ardından 6 Martta cemiyetin ilk toplantısı yapılarak başkanlığına Hacı Fehim Efendi, muhasipliğine ise Dursun Beyzade Cevat Bey seçilmiştir. Cemiyetin Erzurum şubesinin kurulduğuna dair izin ise 10 Mart 1919'da verilmiştir. (Sarıkoyuncu, 2003: 348) Böylece Milli Mücadele'nin Doğu Anadolu'daki ilk teşkilatlanması meydana getirilmiş oluyordu. (Çil, 2015: 4)

Vilâyât-1 Şarkiyye Müdafaa-i Hukuk-1 Milliye Cemiyeti Erzurum şubesine İzmir'in Yunanlılar tarafindan işgal edildiği haberi telgrafla bildirilince Erzurum halkı adeta galeyana gelmiştir. Çünkü İzmir ve civarında Yunanlılar tarafından yapılan haksız işgallerin benzerinin daha sonra Erzurum ve çevresinde Ermeniler tarafından yapılacağı bilinmekteydi. (Konukçu: 21) Bu nedenle 18 Mayıs 1919'da Lala Paşa Camii yanındaki Yakutiye meydanında toplanıp İzmir'in işgaline karşı bir protesto mitingi düzenlenmiş ve burada yapılan ateşli konuşmalarla halk, işgale karşı tepkilerini topyekûn ortaya koymuşlardı. Hınıs, Pasinler ve Bayburt ilçeleri de "ne millet ne de ordu, mevcudiyetine karşı yapılmış bu haksız tecavüzü hazm ve kabul etmeyecektir" demek suretiyle İzmir'in işgaline karşı tepkilerini göstermiş̧lerdi. (Himoğlu, 2015: 92) Erzurum'da 2 Haziran 1919'da ikinci bir miting daha yapılmış, bu mitingde konuşan Hüseyin Avni (Ulaş) Bey ve diğer bazı kişiler tarafından İzmir'in işgali nedeniyle Yunanlılar ve İtilaf Devletleri bir kez daha protesto edilmiştir. Daha önce Ermeni zulüm ve vahşetine maruz kalan Erzurumlular bu suretle İzmir'deki vatandaşların acılarına ortak olduklarını ispat etmişlerdi. (Konukçu: 16)

Bu sırada M. Kemal Paşa'nın henüz Samsun ve çevresinde faaliyetlerini sürdürürken, Vilâyât1 Şarkiyye Müdafaa-i Hukuk-1 Milliye Cemiyeti'nin gayretleri sonucu 17-21 Haziran 1919 tarihleri arasında Erzurum'da bir "Vilayet Kongresi" toplanmıştır. Kongreye Erzurum, Bayburt, Pasinler, Tortum, Yusufeli, İspir, Narman, Kiğğ, Hınıs ve Tercan'1 temsilen 21 delege katılmıştır. Burada Doğu Anadolu'daki propagandalar, milli duygular ve hürriyet konuları üzerinde durularak Osmanlı Devleti'nden kopmamak için her türlü fedakârllğa katlanma ve Ermeni istilasına karşı şiddetle karş1 koyma kararı alınmıştır. (Konukçu: 125-126) Cemiyetin "Heyet-i Faale" adı verilen idarecileri ayrıca, 10 Temmuz 1919'da Erzurum'da Doğu illeri adına bir kongre toplama kararı almışlardı. (Çil, 2015: 5)

Vilayet Kongresi'nin bu kararının ardından, Vilâyât-1 Şarkiyye Müdafaa-i Hukuk-1 Milliye Cemiyeti ile Trabzon Muhafaza-i Hukuk-1 Milliye Cemiyeti anlaşarak 10 Temmuz 1919'da Erzurum'da bir doğu illeri kongresi toplanması hususunda fikir birliğine varmışlardır. Bu nedenle M. Kemal Paşa henüz Amasya'da iken bu kongreye delege göndermeleri için doğu illerine davette bulunulmuş ve kongreye katılacak kişilerin yola çıkarılması ve yolculuk esnasında kendilerine gereken kolaylıkların sağlanması için valilik ve kumandanlıklara gerekli tebligatlar yapılmıştı. M. Kemal Paşa da Erzurum’a 
geldiği ilk andan itibaren de bu kongrenin hazırlıkları ve gerekli tedbirlerin alınması ile ilgilenecektir. (Korkmaz, 1994: 32; Konukçu, 1992: 810)

\section{B. Mustafa Kemal Paşa'nın Erzurum'a Gelişi}

M. Kemal Paşa Samsun'a çıktığı 19 Mayıs 1919'dan Erzurum'a varacağı güne kadarki yaklaşık 45 günlük süre zarfinda $690 \mathrm{~km}$ 'lik yol kat ederek son derece önemli faaliyetlerde bulunmuştu. (Aydoğan, 2000: 135) Bu faaliyetler sırasında Erzurum'a gidip orada milletle el ele vererek çalışması gerektiğini anlamıştı. Bunun için gerekli olan otomobil ve benzin ihtiyacını Kazım Karabekir Paşa'nın karşılaması ve gizlice yapılan hazırlıkların tamamlanması üzerine beraberindekilerle birlikte 26 Haziran sabahı Amasya'dan ayrılarak, bir süre Tokat ve Sivas'ta kalmış, 27-28 Haziran gecesi sabaha doğru Sivas'tan Erzurum'a doğru yola çıkılmıştır. (Konukçu: 779; Korkmaz, 1994: 31) Bu sırada, onun Anadolu'da bulunmasından rahatsızlık duyan İngilizler Amasya'da alınan kararları öğrenmiş ve İstanbul hükümetine yönelik baskılarını daha da arttırmışlardı. Mabeyn Başkâtipliği'nden 2 Temmuz 1919'da M. Kemal Paşa'ya çekilen telgrafta kendisinin bazı tertibat ve teşebbüslere girişmesinin İngilizlerin dikkatini çektiği ve bu nedenle hükümete baskı yapmaya başladıkları ifade edilerek, istifa ederek ya İstanbul'a dönmesi veyahut iki ay süreliğine hava değişimi alarak istediği yerde istirahate çekilmesi tavsiye edilmişti. Bu telgraf Erzurum'a gitmekte olan M. Kemal Paşa'ya Erzincan'da ulaşmıştı. (Cebesoy, 2010: 160)

M. Kemal Paşa, yanında Hüseyin Rauf (Orbay) Bey, Manastırlı Miralay Kâzım (Dirik) Bey, Binbaşı Hüsrev (Gerede) Bey, Miralay İbrahim Tâli (Öngören), Refik (Saydam) Bey, yaver ve zabitler olduğu halde Sivas'tan ayrıldıktan sonra bir haftalık yorucu bir yolculuğun ardından 3 Temmuz 1919'da ikindiye doğru Ilıca'ya (Aziziye) varmışlardı. Erzurum'un eski bir âdetine göre şehre batı tarafından gelen misafirler, şehirden ilk görünen yer olan Ilıca'da karşılanır ve şehir merkezine kadar kendilerine eşlik edilirdi. (Dursunoğlu, 1998: 71-72; Korkmaz, 1994: 31) Bu nedenle M. Kemal Paşa ve beraberindekiler Ilıca'ya vardıklarında XV. Kolordu Kumandanı Kâzım Karabekir Paşa, Erzurum Valiliği'nden alınan Ahmet Münir (Akkaya) Bey, Bitlis Valiliği'nden ayrılıp İstanbul'a gitmek üzere olan Mazhar Müfit (Kansu) Bey, Vilâyat-i Şarkiyye-i Müdafaa-i Hukuk-1 Milliye Cemiyeti Erzurum Şubesi Reisi Hoca Raif Efendi ve cemiyetin idare heyeti tarafindan karşılanmışlardır. IX. Ordu Müfettişi ve Fahri Yaver-i Hazret-i Şehriyari ünvanına sahip olan M. Kemal Paşa, padişah yaveri kordonu ile göğsünde altın imtiyaz madalyasını da taşımaktaydı. (Karabekir, 1969: 67; Kansu, 1997: 25; Kocahanoğlu, 2005: 188; Selvi, 2000: 94; Goloğlu, 1968: 63)

M. Kemal Paşa burada ilk önce Kazım Karabekir Paşa ve M. Müfit Bey ile selamlaşmış, ardından Kâzım Karabekir Paşa tarafından Ilıca'da hazırlatılan çadırlarda bir süre çay içilerek sohbet edilmiștir. (Kansu, 1997: 26-27; Konukçu: 783) Bu sırada batı yönünden gelen yirmi otuz kişilik bir grup M. Kemal Paşa ve yanındakilerin dikkatini çekmiştir. Yaklaştıklarında grubun önünde bulunan ve "Mezararkalı Mevlüt Ağa" adlı ihtiyar bir adamla M. Kemal Paşa arasında dikkat çeken bir konuşma geçmiştir. M. Kemal Paşa, Mevlüt Ağa’ya nereden gelip, nereye gittiğini sormuş, Mevlüt Ağa ise verdiği cevapta I. Dünya Savaşı sırasında Erzurum'dan Çukurova'ya göç ettiğini ve orada geçiminin son derece iyi olduğunu, fakat Erzurum ve çevresinin Ermenilere verileceğine dair şayiaların duyulması üzerine memleketinin elden çıkmasına mani olmak için yeniden Erzurum'a döndüğü ifade etmiştir. (Dursunoğlu, 1998: 72-73) Aldığı cevap üzerine M. Kemal Paşa'nın yurdun düşmandan kurtarılabileceğine dair inancı bir kat daha artmıştır. Bu kısa molanın ardından Erzurum'a doğru yola çıkılmıştır. "İstanbul Kapı" adındaki asıl karşılama mevkiine gelindiğinde, kalabalık bir halk topluluğu, XV. Kolordu İhtiram Kıtası ve Kâzım Karabekir Paşa'nın oluşturduğu "Şehit Yavruları" tarafindan parlak bir karşılama töreni yapılmıştır. (Selvi, 2000: 94) M. Kemal Paşa burada kendisini karşılamaya gelen askerleri selamlamış, ardından sivil zevatın ellerini sıkarak öğrencilerin başını okşamak suretiyle kendisine gösterilen derin hürmete karşı memnuniyetini belirtmiştir. (Kocahanoğlu, 2005: 188) Erzurum'da kaldıkları süre boyunca genellikle M. Kemal Paşa ve Rauf Beylerle birlikte dolaşan Hüsrev (Gerede) Bey'in verdiği bilgilere göre, Erzurum ve çevre köylerinde bulunan bütün halk Hamidiye Kahramanı adıyla Rauf Beyi tanımakta, fakat M. Kemal Paşa'yı tanımamaktaydı. Kâzım Karabekir de bu durumu teyid etmektedir. (Önal, 2003: 66; Karabekir, 1960: 66)

Karşılama merasiminin ardından M. Kemal Paşa, kendisini daha yakından görmek isteyen kalabalığa kısa bir konuşma yaptıktan sonra şehrin ileri gelenleriyle de görüşerek onlara düşüncelerini ve gayelerini açıklamıştır. Burada gördüğü ilgi ve yakınlığı 1924 Erzurum depremi nedeniyle şehre ikinci gelişinde şu şekilde ifade etmiştir: "Benim buraya gelişim, bütün ulusun ateşten bir çember içine 
alınmış olduğu bir zamana rastladı. Bütün ulus, bu çemberin içinden çıkacağını düşünüyordu. Memleketin batısı, düşman ayaklarına terkedilmiş ve oradaki halk silaha sarılmış, buranın ahalisi ise memleketin felaketten kurtulması için ayağa kalkmış bir durumdaydı. Ben, işte böyle bir zamanda Erzurum'a geldim. Burada gördüğ̈̈m içtenlik, mertlik, gönülden bağglllk benim memleketi kurtarmak için her türlü özveriyi yapmam konusundaki azim ve gücümü artırmıştı". (Aydoğan, 2000: 136-137)

Törenin ardından M. Kemal Paşa ve beraberindekiler, Ordu Kumandanlığı Karargâhı olarak hazırlanan Erzurum Müstahkem Mevkii Kumandanlığı binasına gitmişlerdir. Bu sırada Refet Bey'in gönderdiği 1 Temmuz tarihli bil telgraf kendisine ulaşmıştır. Refet Bey söz konusu telgrafta, İstanbul'a çağrılamaması için ordu müfettişliği ve askerlik görevinden istifa etmesini tavsiye etmiştir. M. Kemal Paşa ise İstanbul ile haberleşmeyi uzatarak zaman kazanmak, böylelikle doğu vilayetlerinin milli mücadeledeki kudret ve gayretleri hususunda bilgi sahibi olmaya çalışmaktaydı. (Goloğlu, 1968: 63)

\section{Mustafa Kemal Paşa'nın Erzurum'daki İlk Faaliyetleri}

M. Kemal Paşa, Erzurum'a geldikten sonra hemen çalışmalara başlamıştır. İlk günden beri her bölge veya vilayette bağımsız olarak faaliyet gösteren müdafaa-i milliye cemiyetlerini birleştirerek tek merkezden idare etmeyi düşünen M. Kemal Paşa, Vilâyat-i Şarkiyye-i Müdafaa-i Hukuk-1 Milliye Cemiyeti'nin Erzurum Şubesini ziyaret ederek Cemiyet Reisi Hoca Raif Efendi ve idare heyeti ile temaslar kurmuştur. Bu sırada Erzurum halkı M. Kemal Paşa ve beraberindekilerin cemiyete giderken geçişini adeta kurtuluşun bir tezahürü kabul etmişlerdir. (Kansu, 1997: 28-29; Dursunoğlu, 1998: 74)

M. Kemal Paşa Erzurum'da kaldığı yaklaşık iki aylık zaman zarfında iki ayrı yerde ikamet etmiştir. Bunlardan ilki, şimdiki Cumhuriyet caddesinde Ulu Camii hizasında Cimcime Sultan Kümbetinin karşısındaki binadır. Bu bina o zamanlar Erzurum Müstahkem Mevkii Kumandanlığına ait olup müfettişlik karargâhı olarak kullanılmaktaydı. Bu binada resmi işlerini yürütmekte ve hemen yanında bulunan küçük ve o dönem için yeni bir binada da ikamet etmekteydi. Milli Mücadeleye katılanların Erzurum'daki ilk grup toplantılarının yapıldığı, kararların alındığı ve M. Kemal Paşa'nın askeri faaliyetlerinin gerçekleştiği bu bina idi. Burada üzerinde bir Avrupa haritası bulunan masanın etrafina toplanarak uzun süre toplantılar yapılmaktaydı. Ancak toplu olarak bir arada bulunabilmek için daha büyük bir binaya ihtiyaç duyulmaktaydı. Bu nedenle $\mathrm{M}$. Kemal Paşa askerlik görevinden ayrıldıktan sonra, Rauf Bey, Mazhar Müfit Bey ve Süreyya (Yiğit) Bey ile şimdiki Çaykara caddesinde yer alan, zengin bir Ermeni tarafından XIX. Yüzyıl sonlarında, derenin kenarındaki yüksek bir alana yaptırılan konağa taşınmıştır. Bu konak, 1915'te Ermeni tehcirinden sonra Tahsin Bey'in Erzurum Valiliği sırasında emvâl-i metruke'den sayılarak Almanya'nın Erzurum Konsolosluğu olarak kullanılmıştı. Bir ara Ermeni çete reislerinin de oturduğu bina, 1918 Martından sonra Erzurum Valisi Münir Bey'e tahsis edilmiști. Ancak valinin İstanbul'a dönmesi üzerine ondan boşalan bu eve M. Kemal Paşa taşınmıştır. O günlerde Erzurum'un en güzel binalarından birisi olan bu konak günümüzde Atatürk Evi müzesi olarak hizmet vermektedir. (Önal, 2003: 61; Himoğlu, 2015: 126; Kansu, 1997: 97-98; Kocahanoğlu, 2005: 191-192; Konukçu, 1992: 790)

İki katlı olan bu evin bir de çatı katı vardı. M. Kemal Paşa ikinci katta, merdivenden çıkınca sağ tarafta bulunan odada kalmaktaydı. Odasında bir karyola, aynalı bir konsol, bir masa ve birkaç tane de sandalye vardı. Evin salonunda ise 15-20 kişilik uzun bir masa ile 20'ye yakın sandalye yer alıyordu. Bu masada hem çalışılıp hem de yemek yenilmekteydi. Yemek sırasında masada bulunan herkesin yeri belliydi ve yemek uzun sürerdi. Çünkü hemen her meseleyi yemek sırasında görüşmek isteyen M. Kemal Paşa, bazen neşeli hikâyeler anlatarak ciddi meselelere renk katardı. Öğlen yemeklerinden sonra ise ilk katta yer alan ve içerisinde piyano bulunan odada kahvesini içer ve misafirlerini kabul ederdi. (Kansu, 1998: 98-1000)

Erzurum'a gelişinin ertesi günü olan 4 Temmuz günü Sultan Mehmet Reşat'ın yerine tahta geçen Vahdettin'in cülusunun yıldönümü idi. Bu nedenle bütün yurtta olduğu gibi Erzurum'da da törenler yapılmıştır. Eskiden mülkiye mektebi olan fakat o zamanlarda hükümet binası olarak kullanılan binaya giden M. Kemal Paşa ve beraberindekiler törene katılmışlardır. M. Kemal Paşa III. Ordu Müfettişliğinin yanı sıra Fahri Yaveri Şehriyari olduğu için İstanbul'a telgraf göndererek padişaha tebriklerini de iletmiştir. (Önal, 2003: 49-50; Konukçu, 1992: 791)

M. Kemal Paşa, Kâzım Karabekir Paşa, H. Rauf Bey, Erzurum Eski Valisi A. Münir Bey, Ordu Müfettişliği Kurmay Başkanı Kâzım Bey, Binbaş1 Hüsrev Bey, Binbaş1 Refik Bey, İzmit Mutasarrıfı Süreyya Bey ve Bitlis Eski Valisi M. Müfit Bey Erzurum Kalesi Muhafızlığına ait küçük bir binada 5 Temmuz akşamı gizlice bir toplantı yapmışlardır. Toplantıda ülkenin içerisinde bulunduğu 
genel durum ve nelerin yapılması gerektiği gecenin geç saatlerine kadar ayrıntılı olarak ele alınmıştır. Burada fikirlerini açıklayan M. Kemal Paşa, büyük bir fedakârlık ve özveriyle saray, hükümet ve işgallere karş1 son nefese kadar mücadele edilmesi gerektiğini, bu doğrultuda kendisinin her şeyi göze aldığını ve her vatan evladının da aynı şeyi yapması gerektiğini ifade etmiştir. Ardından hedeflerini "millî hâkimiyete dayanan ve kayıtsız şartsız bağımsız bir Türk devleti kurmak ve bu hedefe mutlaka ulaşmak" olarak belirttikten sonra kendisinin bu kutlu yolda ulusun bir ferdi olarak çalışacağını, fakat kendinde azîm, imkân ve cesaret görmeyenlerin henüz işin başındayken aralarından ayrılabileceklerini söylemiştir. Ailevi sebepleri nedeniyle fiilen görev alamayacağını belirten Eski Vali A. Münir Bey dışındaki herkes M. Kemal Paşa'ya bağlılık sözü vermiş ve onu hareketin lideri olarak benimsediklerini belirtmişlerdir. (Korkmaz, 1994: 31; Kansu, 1997: 30-35; Dirik, 2016: 65; Önal, 2003: 50-51; Selvi, 2000: 97; Sarihan, 1994: 363)

\section{M. Kemal Paşa'nın Sine-i Millete Dönmesi}

Mustafa Kemal Paşa Samsun'a çıkmasının ardından yaptıkları nedeniyle İngilizler ve dolayısıyla İstanbul hükümetinin dikkat ve tepkisini çekmişti. Hükümet nazarında artık bir âsi olup, onunla mücadele edilmesi gerekmekteydi. Bu nedenle 7-8 Temmuz 1919 gecesi bizzat Padişah Vahdettin tarafindan telgraf başına çağrılmış ve derhal İstanbul'a dönmesi istenmiştir. M. Kemal Paşa ise padişahın bu isteğini reddedince IX. Ordu Müfettişliğinden alınmıştır. Bunun üzerine M. Kemal Paşa aynı akşam 22:50'de Harbiye Nezareti'ne ve 23:00'da ise padişaha telgraf çekerek müfettişlik görevinin yanı sıra çok sevdiği askerlik mesleğinden de istifa ettiğini ve sine-i millete döndügünü bildirmiştir. (Korkmaz, 1994: 33; Kansu, 1997: 37-39; Kocahanoğlu, 2005: 191; Goloğlu, 1968, 64) Böylece fevkâlade yetkilerle Anadolu'ya gönderilen M. Kemal Paşa sıradan bir vatandaş durumuna gelmişti. Ancak Kâzım Karabekir Paşa, hiçbir askeri yetki ve sıfatı olmamasına rağmen M. Kemal Paşa'ya ziyaret ederek, kolordusuyla birlikte emirlerine amade olduğunu söylemiştir. M. Kemal Paşa ile birlikte H. Rauf Bey, Refik Bey, Hüsrev Bey, Müfettişlik Kalem Amiri Hayati Bey, Yaver Cevat Abbas Bey ve Muzaffer Bey de kendiliklerinden ordudan ayrılarak milletin birer ferdi olarak M. Kemal Paşa ile beraber milli mücadeleye devam etme kararı almışlardır. Yalnızca Miralay Kâzım Bey Erzurum Kale Kumandanlığına atandığı için askerlikle ilişkisini kesmemiştir. (Karabekir, 1960: 64; Selvi, 2000: 97 98; Kocahanoğlu, 2005: 192; Konukçu, 1992: 801)

M. Kemal Paşa askerlik görevinden ayrıldıktan sonra hiçbir ünvânı olmamasına rağmen en büyük bağlılık ve vefayı kuşkusuz Kâzım Karabekir Paşa'dan görmüştü. (Kocahanoğlu, 2005: s. 194) 9 Temmuz günü Erzurum Vilayeti'ne gönderdiği yazıyla istifa ettiğini bildirmiş, Süleyman Necati Bey de Albayrak Gazetesi'nde “Anafartalar'da ulusun onurunu, tarihin bugünkü kuşaklarından beklediği görevi gür sesiyle yükselten bu sayın komutanı, bugün de Milli Mücadele'nin başında görmek mutlu bir temâşâdır" demek suretiyle onun bu kutlu mücadelesinde bütün Erzurumluların kendisinin yanında olduğunu ifade etmeye çalışmıştır. (Aydoğan, 2000: 146-147) Ayrıca, bütün Erzurum halkı ve Vilâyât1 Şarkiyye Müdafaa-i Hukuk-1 Milliye Cemiyeti'nin Erzurum Şubesinin gösterdiği güven ve yakınlığa da mazhar olmuştur. Çünkü Türk milletinin sıradan bir ferdi gibi sivil olarak vatan ve milletin tam bağımsızlığı için çalışacağına söz verdiği için Erzurum halkı da kendisinden yana olmuştu. Hatta cemiyetin idare heyeti, 10 Temmuzda M. Kemal Paşa'yı cemiyetin reisliğine, H. Rauf Bey'i de reis vekilliğine getirdiğini kendisine iletmiş ve birlikte çalışacağı beş kişiyi daha belirlemişti. Bunlar: Hoca Raif Efendi, Emekli Binbaşı Süleyman Bey, Emekli Binbaşı Kâzım Bey, Süleyman Necati Bey ve Dursunzade Cevat Bey idi. Ayrıca cemiyet, İstanbul'da bulunan genel merkezine telgraf çekmek suretiyle genel merkez adına fikir beyan etme ve oy kullanma yetkisinin de M. Kemal Paşa'ya verilmesini istemiştir. Bu durum askerlikten istifa ettiği için üzgün olan M. Kemal Paşa'yı son derece mutlu etmişti. Çünkü böylece ilk defa sivil bir kuruluş tarafından bağrına basılmıştır. (Korkmaz, 1994: 44; Selvi, 2000: 100; Tansel, 1991: 48) 


\section{E. Kongre Hazırlıkları}

Erzurum Kongresi'nin 10 Temmuzda toplanması kararlaştırılmış olmasına rağmen delegeler şehre vaktinde gelemediği için kongrenin açılışı Meşrutiyetin yıldönümü olan 23 Temmuza ertelenmişti. (Baykal: 1969) Ancak kongrenin 10 Temmuzda toplanacağı düşünen Albay Rawlinson, M. Kemal Paşa'yı evinde ziyaret baskı yapmaya çalışmıştır. Rawlinson, M. Kemal Paşa ve Kâzım Karabekir Paşa Milli Mücadelenin ileri gelenleri ile yaptı̆̆ 1 görüşmelerde kongrenin toplanmaması, toplansa bile M. Kemal Paşa'nın katılmaması tavsiyesinde bulunmuş, aksi takdirde doğu vilayetlerinin mütarekeye dayanılarak işgal edilebileceği tehdidinde bulunmuştur. Bu durum karşısında son derece sinirlenen M. Kemal Paşa ise kongrenin kesinlikle toplanacağını çünkü milletin buna karar verdiğini belirterek, İngilizlerden veya Rawlinson'dan müsaade istenmediğini belirtmiştir. Rawlinson bu defa, kongrenin toplanması halinde güç kullanılarak dağıtılacağını söyleyince M. Kemal Paşa "Türk milletinin mecburi ve zaruri olarak kuvvete, kuvvetle karşı koyarak milletin kararının yerine getirileceğini, ne pahasına olursa olsun kongrenin toplanacağını" kesin bir dille ifade etmiştir. (Çay, 2016: 221-274; Konukçu, 1999: 67)

Kongreye katılacak delegeler bu süre zarfinda yavaş yavaş Erzurum'a gelmeye başlamışlardı. Erzurum I. Dünya Savaşı'nda Rus işgaline uğradığından ekonomik ve fiziki durumu son derece kötü olup, adeta harap bir şehir görünümündeydi. $\mathrm{Bu}$ nedenle kongrenin düzenli bir şekilde gerçekleştirilebilmesi için yapılan hazırlıklara Erzurum halkı da büyük destek vermiştir. (Selvi, 2000: 103-104) Öncelikle gelecek olan delegeleri karşılamak ve onlara kalacak yer ayarlamak için Vilâyât-1 Şarkiyye Müdafaa-i Hukuk-1 Milliye Cemiyetinin üyeleri arasında iş bölümü yapılmıştı. Buna göre cemiyet öncelikle 42 mahallesi bulunan şehri 9 bölgeye ayırarak her bölgeye bir görevli tayin etmiştir. $\mathrm{Bu}$ görevliler tarafından, şehre gelecek delegelerin masrafları için bölgesinde bulunan halktan para, yatak ve sofra malzemesi temin edilmesinin yanı sıra delegelere hizmet etmeleri için uygun ücret karşılığında hizmetçiler bile tutulmuştu. (Çil, 2015: 7) Birkaç kişi de delegelerin kalacağı yerleri, kongrenin toplanacağ Süleyman Necati Bey ise Erzurum'da çıkardığı Albayrak Gazetesi'nin o günkü nüshasını düzenleyerek "heyet-i faale" toplantılarında kararlaştırılacak nizamname tasarısını yazacaktı. Cemiyet Reisi Hoca Raif Efendi ise şehir merkezine gelecek delegeleri karşılayacaktı. (Dursunoğlu, 1998: 79) Kongreye katılmak üzere şehre ilk olarak Trabzon delegeleri ulaşmıştı. Trabzon'dan 5 Temmuzda yola çıkan delegeler Erzurum'a geldiklerinde Hacı Dede Ağa'nın konağında ağırlanmışlardır. (Himoğlu, 2015: 111-112)

Kongreye Erzurum'u temsilen M. Kemal Paşa ile H. Rauf Bey'in katılması kararlaştırılmasına rağmen bu husus tartışmalara yol açmıştı. Ancak Kâzım Karabekir Paşa'nın müdahale etmesi üzerine Emekli Binbaşı Kâzım (Yurdalan) ve Cevat (Dursunoğlu) istifa ederek yerlerini M. Kemal Paşa ile H. Rauf Bey'e vermişler, kendileri de daha sonra Pasinler ve Tortum'dan delege seçilmişlerdir. (Korkmaz, 1994: 44; Dursunoğlu, 1998: 80-81; Goloğlu, 1968: 65) Bu sırada Erzurum Kongresi'nin yanı sıra daha sonra Sivas'ta toplanacak kongrenin hazırlıkları ile de meşgul olan M. Kemal Paşa kolordulara gönderdiği gizli yazı ile hükümetin vatan ve millet aleyhinde yapması muhtemel tebliğlerin önüne geçebilmek için, haberleşme kanalı olan önemli merkezlerde gerektiği zaman uygulanmak üzere acilen tedbirler alınmasını ve bunun hükümet ile telgraf memurlarına hissettirilmeden yapılmasını istemiştir. (Sarıhan, 1994: 363-373)

Kongrenin toplanmasından önce M. Kemal Paşa ve beraberindekiler kongre hazırlıklarından geri kalan vakitlerde zaman zaman çevreyi gezme imkânı da bulmuşlardı. Örneğin 19 Temmuz günü cirit alanındaki spor müsabakalarını izlemişlerdir. Şehir meydanı eski haline nazaran düzenlenmiş, erkek ve kadınlar için oturma yerleri yapılmak suretiyle modern bir yapıya kavuşturulmuştu. (Önal, 2003: 57) Etrafı çevirtilen ve daha sonraları "Çocuklar Ordusu Talimgâhı" adı verilen bu alanda cirit, güreş ve koşu gibi yarışmalar düzenlenmekteydi. Kâzım Karabekir Paşa'nın şehre gelişinden sonra bu oyunlara futbol, bisiklet ve benzeri birçok spor daha eklenmişti. Özellikle atına ve biniciliğine güvenenler bu alana gelerek yarışlara katılır ve kendilerini kalabalık bir seyirci kitlesi izlerdi. Cuma günü ile Pazar akşamları düzenlenen bu etkinlikler şehir halkının başlıca eğlencesiydi. Kadınlar bu meydandaki eğlence ve müsabakaları seyre gelmekte olup, kız öğrencilerin oluşturduğu "Şefkat Bacıları" ise hasta bakıcılık ve ilk yardım hizmeti vererek sağlık talimleri yapmaktaydılar. (Çay, 2016: 263; Canım, 2010: 26)

23 Temmuz 1919'da Erzurum Kongresi'nin toplanabilmesi için bugünkü kongre caddesinde bulunan Sansaryan Mektebi hazırlanmıştı. Sansaryan adında zengin bir Ermeni tarafından kurulan bu 
okul, dönemine göre ileri düzeyde bir eğitim vermekteydi. Okulun öğretmenleri Almanya'da eğitim almışlar ve Doktor Moryan adında son derece iyi eğitimli bir müdürü vardı. Okulda biyoloji, jeoloji ve müzik gibi henüz Osmanlı'da olmayan dersler verilmekteydi. Ayrıca Erzurum'da "satır buzu" denilen buz pateni ile "eğri kayak kızağı" olarak adlandırılan kayak gibi o dönemde Türkiye'de henüz görülmemiş spor branşları da öğretilmekteydi. (Önal, 2003: 57) Bu okulun 12 metre genişliğinde ve 20 metre uzunluğundaki salonuna toplanacak kongre için bir başkan, iki de kâtip kürsüsü koyulmuştu. $\mathrm{Bu}$ kürsülerin üzeri halı ve seccadelerle kaplanmıştı. (Dursunoğlu, 1998: 79)

\section{F. Erzurum Kongresi}

10 Temmuzda açılması kararlaştırılan fakat delegelerin zamanında gelememesi nedeniyle ertelenen Erzurum Kongresi nihayet 23 Temmuz 1919'da parlak bir şekilde çalışmalarına başlamıştır. (Sarıhan, 1994: 1) Öğlene doğru mektebin önüne üç otomobil gelmiş ve en öndeki otomobilden M. Kemal Paşa, yaveri ve Kâzım Karabekir Paşa, ikinci sıradaki otomobilden Rauf Bey, Mazhar Müfit Bey, İbrahim Süreyya Bey ile bir iki kurmay subay inmiştir. Kongrede hazır bulunan delege sayıları hakkında farklı bilgiler mevcut olsa da yaklaşık 60 kişi olduğu kabul edilebilir. (Konukçu, 128) En yaşlı üye olan Trabzonlu Eyüpoğullarından İzzet Bey’in, Vilâyat-i Şarkiyye-i Müdafaa-i Hukuk-1 Milliye Cemiyeti Erzurum Şubesine jesti üzerine Hoca Raif Efendi tarafından kongre açılmış, ardından Şiran Delegesi Hasan Efendi tarafindan Arapça dua okunmuştur. (Dursunoğlu, 1998: 88-89; Dayı, 1997: 26) İlk oturumda, salonun en ön sıralarında bulunan Erzincan delegesi Hacı Şeyh Fevzi Efendi'nin yanına oturan M. Kemal Paşa, yapılan seçim sonunda kongre başkanlığına seçilmiştir. Başkan seçilmesi üzerine kürsüye çıkarak delegelere bir teşekkür konuşması yapan M. Kemal Paşa'nın üzerindeki mirliva üniforması ile padişah kordonu bulunması kendisini birtakım münasebetsiz eleştirilere maruz bırakmıştır. Gümüşhane Delegesi Zeki Bey, M. Kemal Paşa'ya hitaben "Paşa! Evvela üniforma ve kordonunu at, ondan sonra kürsüye gel! Milli kuvvet askeri tahakküm şekline girmesin" diyerek tepkisini göstermiştir. (Konukçu, 1992: 816; Karabekir, 1960: 83; Karabekir, 2009: 612; Sürmeli, 1997: 29-41)

M. Kemal Paşa yapmış olduğu konuşmada, I. Dünya Savaşı sonrası dünyada ve Türkiye'de hâkim olan siyasi durum hakkında bilgi vermiştir. Bu konuşmayı kendisi şu sözlerle ifade etmiştir: "Ve milletin mukadderatına hâkim bir milli iradenin, ancak Anadolu'dan doğabileceğini belirttim. Milli iradeye dayanan bir millet meclisinin meydana getirilmesini ve gücünü milli iradeden alacak bir hükümetin kurulmasını, kongre çalışmalarının ilk hedefi olarak gösterdim". (Çil, 2015: 45)

Kongre çalışmalarına başladığında Erzurum'da bunlar olurken İstanbul'da da önemli gelişmeler yaşanmaktaydı. İstanbul hükümeti, Erzurum Kongresi'nin toplanacağını önceden bildiği için kongreyi engellemek için bazı girişimlerde bulunmuştu. Sadrazamlık, dâhiliye ve harbiye nezaretleri kongrenin toplanmasını engelleyip milli mücadelenin halk desteğinden yoksun kalmasını sağlamak için elinden gelen her şeyi yapmaktaydı. (Selek, 2010: 232) Ancak bütün gayretlerine rağmen kongrenin toplanmasını önleyemeyince, M. Kemal Paşa'yı tutuklatarak Milli Mücadele hareketini akim bırakma yoluna başvurulmuştu. Çünkü kongrenin toplanması İstanbul Hükümetini olduğu kadar İstanbul'daki İtilaf Devletleri temsilcilerini telaşlandırmıştı. Özellikle General Franchet d'Esperey, hükümeti tazyik etmeye başlamıştı. Bunun üzerine Milli mücadeleyi bir ayaklanma, isyan olarak niteleyen hükümet, M. Kemal Paşa ile Rauf Bey için 30 Temmuzda yakalama kararı çıkarmıştır. Harbiye Nazırı Nazım Paşa bu yakalama kararını uygulaması için Kâzım Karabekir Paşa'dan yardım talebinde bulunmuş, fakat M. Kemal Paşa'ya hayatının belki de en zor günlerinde destek vererek yanında olan Kâzım Karabekir Paşa 6 Ağustos'ta İstanbul'a gönderdiği telgrafta, M. Kemal Paşa'yı tutuklayamayacağını şu sözlerle belirtmişti: "Doğu vilayetlerinde hayat endişesinden doğmuş olan ve bugünkü durumda M. Kemal Paşa ve Rauf Bey'in tesirleri olmadı̆̆l, kongreye herkes tarafindan hürmet ve tazimle kabul edilen bu iki zâtın, siyasi durumumuzu daha fazla idrak etmiş olduklarından, bilakis hükümetimizin mevkiini düşünerek, mevcut kuvayı milliyeyi daha sakin ve tedbirli bir şekilde icra ile iyi şekilde idare ettikleri açıç̧a görülmektedir". (Cebesoy, 2010: 181; Çil, 2015: 13)

23 Temmuz-7 Ağustos 1919 tarihleri arasında devam eden Erzurum Kongresi 14 günlük süre zarfında 13 toplantı yapmıştır. (Çil, 2015: 9) Bu toplantılar sonucu Türk milletinin varlığı ve istikbâli açısından hayati önem taşıyan birtakım kararlar alınmıştır. Bunlar: Milli sınırlar içerisinde vatan bir bütündür, parçalanamaz. Manda ve himaye kabul edilemez. Osmanlı ülkesinin bütünlüğü için milli güçleri ve milli hâkimiyeti hâkim kılmak esastır. Her türlü işgal ve yabancı müdahalesine karşı millet ittifak halinde mukavemet edecektir. Hristiyan unsurlara siyasi hâkimiyet ve sosyal dengeyi bozabilecek ayrıcalıklar verilemez. Kuvâyı Milliyeyi âmil ve milli iradeyi egemen kılmak esastır. Milli meclisin 
derhal toplanmasına ve hükümet icraatlarının meclis denetimine alınması için çalışılacaktır. Vatanın maruz kaldığı üzücü hadiseler sonunda milletin vicdanından doğan Vilâyât-1 Şarkıye Müdâfa-1 Hukuk1 Milliye Cemiyeti her türlü particilik akımından uzak olup, bütün İslam vatandaşları cemiyetin üyesidir. Kongre tarafindan seçilen bir de Temsil Heyeti kabul edilmiştir. Trabzon Muhafaza-i Hukuk-1 Milliye Cemiyeti ile Vilâyât-1 Şarkıye Müdâfa-1 Hukuk-1 Milliye Cemiyeti, Şark-i Anadolu Müdafaa-i Hukuk Cemiyeti adı altında birleştirilmiş ve başkanlığına da M. Kemal Paşa getirilmiştir. (Karabekir, 2009: 614; Çil, 2015: 14; Konukçu, 129; Tansel, 1991: 55-56)

Erzurum Kongresi'nin devam ettiği günlerde 28 Temmuzda M. Kemal Paşa ile Albay Rawlinson arasında uzun bir görüşme yapılmıştı. M. Kemal Paşa bu görüşmede Albay Rawlinson'a kongrede alınacak kararlar hakkında kendisini bilgilendireceğini söylemişti. 6 Ağustos'a gelindiğinde bu defa Rauf Bey'in evinde yaklaşık üç buçuk saat süren ikinci bir görüşme daha yapılmıştır. Burada, Milli Mücadele hareketinin gayesi ve gelecekte ortaya çıkacak durum hakkında değerlendirmelerde bulunulmuştur. Erzurum Kongresinden sonra alınan bu kararlar yurdun her tarafina dağıtılmış̧ı. Batı Anadolu'da Yunanlılara karşı mücadele eden Kuvayı Milliye kuvvetleri üzerinde de pek büyük manevi etki yaratmıştır. (Çay, 2016: 221-274; Selvi, 2000: 173; Özalp, 1971: 43)

\section{G. Kongre Sonrası M. Kemal Paşa}

Erzurum Kongresi, M. Kemal Paşa'nın muhafaza ettiği gaye ve emellere uygun şekilde sonuçlanmış, alınan kararlarla doğu vilayetlerinin birlik ve bütünlüğünü sağlayan bir teşekkül meydana getirilmişti. Fakat M. Kemal Paşa kongrenin sona erdiği gece son derece düşünceliydi. Çünkü her gün ağırlığını daha da hissettiren işgal şartları ve ülkenin içerisinde bulunduğu siyasi durum ona ağır bir sorumluluk duygusu yüklemişti. (Kansu, 1997: 127) O günlerde Sivas Kongresi'nin hazırlıkları da devam etmekte olup, kongrenin açılmasına kadar M. Kemal Paşa ile Rauf Bey'in güvenlikleri ve kongrenin selameti açısından Erzurum'da bulunmaları uygun görülmüştü. 25 Ağustos akşamı Kâzım (Yurdalan) ile Necati ve Cevat Beyler M. Kemal Paşa'yı evinde ziyarete gitmişlerdi. M. Kemal Paşa Osmanlı Meclis-i Mebusanı'nın biran önce açılması gerektiğinden bahsederken, Erzurum'dan mebus seçilmek istediğini söyleyerek ilk ihtilal adımını attığı bu kadim şehri temsil etme şerefini her yere tercih edeceğini ifade etmiştir. Çünkü kongre günlerinde Erzurum'da gördüğü samimiyet, mertlik, fedakârlık, M. Kemal Paşa'nın gönlünde unutulmaz izler bırakmıştır. Bu nedenle 26 Ağustos günü toplanan Şarki Anadolu Müdafaa-i Hukuk-1 Milliye Cemiyeti Erzurum Heyet-i Merkeziyesi, M. Kemal Paşa'ya Erzurum hemşehriliğini teklif etme kararı almış ve bunu kendisine resmi yazıyla bildirmiştir. M. Kemal Paşa, Şarki Anadolu Müdafaa-i Hukuk-1 Milliye Cemiyeti Erzurum Heyet-i Merkeziyesine gönderdiği 27 Ağustos 1919 tarihli telgrafinda, "Erzurum hemşehriliğini teklif suretiyle hakkımda bu kerre de izhar buyrulan asâr-ı muhabbet ve samimiyetin müteşekkiriyim. Tarihi olan Erzurum'un bu erler yatağının hemşehrileri meyânında bulunmak, âcizleri için en büyük sa'adettir. Erzurum'un nüfusuna kaydımın icrası için icap eden muameleye tevessül edildiğini beyan ve revabıt-ı kalbiye ve samimanemi te'yîd eylerim efendim" demek suretiyle memnuniyetini ifade etmiştir. Böylece "Türklüğün Anadolu'daki en eski kalesine, en kahraman şehrine asrın en büyük Türk'ü hemşehri olmuştur”. (Atam, 1991: 63; Dursunoğlu, 1998: 112-113)

28 Ağustos akşamı M. Kemal Paşa ve Heyet-i Temsiliye üyeleri ile birlikte Kâzım Karabekir Paşa'nın evinde son defa hep birlikte genel durum değerlendirmesi yapılmıştır. Sivas'a gidecek olan kişiler, ülkenin batısı ve güneyinin işgale uğradığı günlerde, hür ve bağımsız bir ülke amaçlayan kararları ülkenin doğusundan yani Erzurum'dan götüreceklerdi. (Karabekir, 1960: 156-157) Ancak M. Kemal Paşa ve beraberindeki heyetin Sivas'a gidebilmesi için yaklaşı 1000 liralık paraya ihtiyaçları vard1, fakat Erzurum'daki cemiyette sadece 80 lira bulunmaktaydı. Heyet-i Faale üyelerinden emekli Binbaşı Süleyman Bey'in kendi istikbali için sakladığı 900 lirayı vermesiyle bu maddi sıkıntı da halledilmiş oldu. (Dursunoğlu, 1998: 111) Maddi sorunun halledilmesinin ardından 29 Ağustos günü M. Kemal Paşa, Rauf Bey, Hoca Raif Efendi ve müfettişlik heyeti, Sivas'a gitmek üzere öğlene doğru Erzurum'dan hareket etmişlerdir. Rahatsız olduğu için yolcu edemediği heyeti Erzurum'un çıkışına kadar dürbünle gözleyen Kâzım Karabekir Paşa, heyetin ardından "hayırlı yolculuk ve hayırlı kongre" sözleriyle dua etmişti. Ona göre, Erzurum'dan doğan istiklâl güneşi, M. Kemal Paşa ve beraberindekilerle birlikte Anadolu'nun içlerine gidiyordu. (Sarıhan, 1994: 75; Selvi, 2000: 176; Karabekir, 2009: 620-621; Karabekir, 1960: 158-159)

Osmanlı Meclis-i Mebusanı için 1919 yılı sonlarında seçim yapılması kararlaştırılmış ve Ali Rıza Paşa hükümeti tarafından vilayet ve mutasarrıflıklara genelge gönderilerek en kısa zamanda mebus 
seçiminin yapılması bildirilmiştir. Bunun üzerine Süleyman, Necati, Kâzım ve Cevad Beyler tarafindan 19 Ekim 1919'da M. Kemal Paşa'ya bir telgraf gönderilerek kendisinin Erzurum'dan mebus aday1 koyulduğu belirtilmiş ve bunu kabul etmesinin Erzurumluları son derece mutlu edeceği bildirilmiştir. Bu sırada Amasya'da bulunan M. Kemal Paşa ise 20 Ekim'de verdiği cevapta "Türklügün mert ve necip merkezini teşkil eden Erzurum'un, Müdafaa-i Hukuk'unun bana tevdi eylemek hususunda, izhâr edilen arzudan dolayl, pek mütehassis ve müteşekkirim. Şimdiye kadar rehber-i hareketittihaz eylediğim esâsat-ı malûme dairesinde bu vazifeyi de sonuna kadar ifâya âzim bulunduğum halde kabul eyleyeceğimin tebliğini rica ederim" demek suretiyle aldı̆̆ tekliften duyduğu memnuniyeti dile getirerek Erzurum'dan mebus seçilebilmek için adaylığı kabul ettiğini bildirmiştir. Aralık 1919'da seçimler yapılmış ve M. Kemal Paşa 268 oy alarak Erzurum mebusu seçilmiştir. (Konukçu, 1999: 91)

\section{SONUÇ}

Tarihin hemen her döneminde önemli bir yere sahip olan Erzurum bu önemini Milli Mücadele Dönemi'nde de korumuştur. Rus işgali ve Ermeni mezalimini yaşadığı için bölgenin Mondros Mütarekesi sonrası Ermenileştirilme ihtimaline karşı milli mücadelenin ilk teşkilatlandığı yerlerin başında gelmektedir. Özellikle Vilâyât-1 Şarkiyye Müdafaa-i Hukuk-1 Milliye Cemiyeti'nin 10 Mart 1919'da Erzurum Şubesi'nin açılmasıyla bu mücadelenin teşkilatlandığı görülmektedir.

İzmir'in 15 Mayıs 1919'da Yunanlılar tarafından işgal edilmesi karşısında duyarsız kalmayan Erzurum ve çevre halkı, 18 Mayıs ve 2 Haziran 1919 tarihlerinde düzenledikleri protesto mitingleriyle bu işgale karşı tepkilerini göstermişlerdir. Benzer acıların Erzurum'da yaşanmaması için 17-21 Haziran 1919'da toplanan Vilayet Kongresi'nde olası bir Ermeni istilası karşısında her türlü mücadele edileceği kararı alınmıştır. Ancak Erzurum'un bu tarihlerdeki en önemli rolü şüphesiz Mustafa Kemal Paşa'nın şehre gelişi ve ardından yaşanan gelişmeler olmuştur. IX. Ordu Kıtaatı Müfettişi olarak 3 Temmuz'da Erzurum'a gelen M. Kemal Paşa, İstanbul hükümetinin baskıları sonucu müfettişlik görevi ve çok sevdiği askerlikten istifa ederek sivil bir yurttaş olarak hayatını Türk milletinin bu kutlu mücadelesine adadığında, tüm şehir halkı onu lider kabul ederek bağrına basmıştır. Böylece Erzurum, M. Kemal Paşa'nın ilk defa sivil kıyafet giydiği yer olmuştur. M. Kemal Paşa'nın burada ikamet ettiği binalar halen onun izlerini ve hatırasını taşımaktadır. O, buradaki günlerini Erzurum ve daha sonra toplanacak olan Sivas Kongresi'nin hazırlıkları ile meşgul olmakla geçirmiştir. 23 Temmuz'da toplanan Erzurum Kongresi 7 Ağustos 1919'da sona ermiş ve Türk milletinin geleceği ile bağımsızlı̆̆ konusunda en önemli kararları almıştır. Burada oluşturulan Heyet-i Temsiliye'ye başkan seçilmek suretiyle de milli mücadele hareketinin önderi olduğu kongre delegeleri tarafindan da kabul edilmiştir. Sivas Kongresi’ne katılmak üzere 29 Ağustos’ta şehirden ayrılmışsa da Erzurum'la olan bağını asla kesmediği görülmektedir. Çünkü 27 Ağustos'da kendisine teklif edilen hemşehriliği kabul etmiş, Aralık 1919'da yapılan seçimlerle toplanan Osmanlı Meclis-i Mebusanı'na da Erzurum mebusu olarak seçilmiştir. Böylece Türk'ün bu önemli şehri, tarihin son dönemlerde yetiştirdiği en büyük Türk'ün memleketi olmuştur.

\section{YARARLANILAN KAYNAKLAR}

“Mustafa Kemal’in Samsundan Gönderdiği İki Mühim Rapor", Belgelerle Türk Tarihi Dergisi, S. 14, İstanbul, 1968, s. 5-9

Albay Rawlinson'un Ortadoğu Hatıraları, (Çev. Cengiz İ. Çay), Tarih ve Kuram Yayınları, İstanbul, 2016

Atatürk'ün Tamim, Telgraf ve Beyannameleri, IV, ATAM Yay., Ankara, 1991

Atatürk’ün Yaveri Cevat Abbas Gürer (Cepheden Meclise Büyük Önder İle 24 Yıl), (Derleyen: Turgut Gürer), Özkaracan Matbaacılık, İstanbul, 2006

AYDOĞAN Erdal, Samsun'dan Erzurum'a Mustafa Kemal, ATAM Yay., Ankara, 2000

BAYAR Celâl, Ben de Yazdım, VIII, İstanbul, 1997

CANIM Rıdvan, Tarihin Nabzını Tutan Şehir: Erzurum, Ankara, 2010

CEBESOY Ali Fuat, Milli Mücadele Hatıraları, Temel Yayınları, İstanbul, 2010

ÇİL Yücel, Erzurum Kongresi'ne Katılan Delegeler, Atatürk Üniversitesi Yayınları, Erzurum, 2015

DAYI S. Esin, Erzurum Kongresi ve Elviye-i Selâse Meselesi, Atatürk Üniversitesi Yayınları, Erzurum, 1997 
DİRIKK Kâzım Doğan, Vali Paşa Kâzım Dirik, Gürer Yay., İstanbul, 2016

DURSUNOĞLU Cevat, Millî Mücadele'de Erzurum, İstanbul, 1998

Erzurum Kongresi İle İlgili Belgeler, (Haz. Bekir S1tk1 Baykal), T.İ.T.E. Yay., Ankara, 1969

GOLOĞLU Mahmut, Erzurum Kongresi, Ankara, 1968

GÖKBILLGIN M. Tayyib, Milli Mücadele Başlarken, I, TTK Yayınları, Ankara, 1959

HIMOĞLU Mücahit, Tarihe Mühür Vuran Şehir Erzurum, Fener Yay., Erzurum, 2015

Hüsrev Gerede'nin Anıları, (Haz. Sami Önal), Literatür Yay., İstanbul, 2003

KANSU Mazhar Müfit, Erzurum'dan Ölümüne Kadar Atatürk'le Beraber, I, TTK Yayınları, Ankara, 1997

KARABEKİR Kâzım, Günlükler (1906-1948), I, YKY Yay., İstanbul, 2009

KARABEKİR Kâzım, İstiklâl Harbimiz, Türkiye Yayınevi, İstanbul, 1960

KILINÇKAYA Leyla - YAVUZ Nuri, "Erzurum Kongresi İçin Yapılan Hazırlıklar", 23 Temmuz

Erzurum Kongresi ve Kurtuluştan Günümüze Erzurum I. Uluslararası Sempozyumu (23-25

Temmuz 2002), ATAM Yay., Ankara, 2003, s. 411-421

KIRZIOĞLU M. Fahrettin, Bütünüyle Erzurum Kongresi (Cumhuriyetimizin 70. Yıldönümüne Armağan), Ankara, 1993

KONUKÇU Enver, “Milli Mücadele’de Erzurum (1918-1923)”, Şehr-i Mübarek Erzurum, Erzurum Belediyesi Kültür Yayınları, Ankara, s. 124-137

KONUKÇU Enver, “Tarih'te Erzurum”, Şehr-i Mübarek Erzurum, Erzurum Belediyesi Kültür Yay., Ankara, s. 1-124

KONUKÇU Enver, Mustafa Kemal Atatürk Döneminde Erzurum, Eser Ofset, Erzurum, 1999

KONUKÇU Enver, Selçuklulardan Cumhuriyete Erzurum, YÖK Matbaası, Ankara, 1992

ÖZALP Kâzım, Millî Mücadele (1919-1922), I, TTK Yay., Ankara, 1971

Rauf Orbay'ın Hatıraları (1914-1945), (Haz. Osman Selim Kocahanoğlu), Temel Yayınları, İstanbul, 2005

SARIHAN Zeki, Kurtuluş Savaşı Günlüğü, II, TTK Yay., Ankara, 1994

SARIKOYUNCU Ali, "Milli Mücadele'de Bir Din Adamı: Erzurumlu Hoca Raif Efendi (Dinç)", 23

Temmuz Erzurum Kongresi ve Kurtuluştan Günümüze Erzurum I. Uluslararası Sempozyumu (23-25 Temmuz 2002), ATAM Yay., Ankara, 2003, s. 337-361

SELEK Sabahattin, Anadolu İhtilali, I, Kastaş Yayınevi, İstanbul, 2010

SELVİ Haluk, Milli Mücadele'de Erzurum, ATAM Yayınları, Ankara, 2000

SÜRMELİ Serpil, "Mustafa Kemal Paşa'nın Erzurum Kongresi Strasında Üniforma Giyme Meselesi", Atatürk Dergisi (Atatürk Üni. Atatürk İlk. Ve İnk. Tar. Enst. Yay.,), Erzurum, Temmuz 1997, s. 29-41 TANSEL Selâhattin, Mondros'tan Mudanya'ya Kadar, II, MEB Yay., İstanbul, 1991

YALÇIN E. Semih - KOCA Salim, Mustafa Kemal Paşa'nın Anadolu'ya Geçişi, Berikan Yay., Ankara, 2012 